\title{
Loss of Production of the Elicitor Protein INF1 in the Clonal Lineage US-1 of Phytophthora infestans
}

\author{
Sophien Kamoun, Theo van der Lee, Grardy van den Berg-Velthuis, Koen E. de Groot, and Francine Govers
}

Laboratory of Phytopathology, Wageningen Agricultural University, Wageningen, and Graduate School Experimental Plant Sciences, the Netherlands. Current address of S. Kamoun: Department of Plant Pathology, The Ohio State University, Ohio Agricultural Research and Development Center, Wooster 44691.

Accepted for publication 16 August 1998.

\begin{abstract}
Kamoun, S., van der Lee, T., van den Berg-Velthuis, G., de Groot, K. E., and Govers, F. 1998. Loss of production of the elicitor protein INF1 in the clonal lineage US-1 of Phytophthora infestans. Phytopathology 88: 1315-1323.

The extracellular protein INF1 of Phytophthora infestans is a member of the elicitin family of protein elicitors known to induce a hypersensitive response on some solanaceous and cruciferous plants. The presence of INF1 elicitin in culture filtrates of $102 P$. infestans isolates from 15 countries was examined. All tested isolates produced INF1 except five isolates

locus DNA fingerprint probe RG57, all the INF1-nonproducing isolates were shown to belong to the clonal lineage US-1 that dominated world populations until the 1980s. Phylogenetic analysis of a set of European US-1 isolates using amplified fragment length polymorphism fingerprint data indicated that loss of INF1 production evolved independently in separate lineages within US-1. DNA and RNA blot hybridizations showed that INF1-nonproducing isolates still retain a copy of the infl gene, whereas little infl mRNA could be detected. Hypothetical interpretations of the evolution in a restricted geographic area of $P$. infestans lineages deficient in the production of a specific elicitor protein are discussed.
\end{abstract} collected in 1976 and 1977 from infected potatoes in East Germany (the former German Democratic Republic). Based on hybridization to the multi-
Additional keywords: avirulence, late blight of potato.
The basis of host specificity in interactions between plants and pathogens has long been a central theme in plant pathology research. In recent years, it became apparent that molecular signal exchange between pathogens and hosts determines the outcome of the interaction (4). Plant resistance to pathogens often involves induction of plant defense responses including localized cell death (hypersensitive response [HR]). These responses are triggered by pathogen molecules termed elicitors. Elicitor molecules, produced directly or indirectly by avirulence genes, are thought to interact with plant receptors encoded by resistance $(R)$ genes, thereby eliciting a signal transduction cascade that leads to activation of defense responses and HR. One consequence of this model is that races of the pathogen mutated in their elicitor or avirulence genes can arise to escape defense responses and become virulent on particular host genotypes $(11,31,39)$. This process of race evolution is thought to contribute to the lack of durability of $R$-gene mediated resistance noted in agronomic systems $(8,39)$.

Phytophthora infestans, a heterothallic oomycete plant pathogen, causes late blight, the most economically important disease of potato worldwide (2). Based on DNA and isozyme fingerprint analyses, it was suggested that before the 1980s a single clonal lineage of the A1 mating type, termed US-1, dominated most populations of $P$. infestans worldwide (18). US-1 isolates are thought to have propagated by asexual reproduction from $P$. infestans strains introduced in the 1840s from Mexico to North America and later to Europe and the rest of the world $(17,18)$. However, recent migration events, probably from Mexico, to Europe and North America of populations of $P$. infestans that include aggressive and A2 mating type strains led to the establishment of a sexual cycle and the displace-

Corresponding author: F. Govers

E-mail address: Francine.Govers@medew.fyto.wau.nl

Publication no. P-1998-1015-01R

(C) 1998 The American Phytopathological Society ment of US-1 populations (12,14-16). Particularly devastating epidemics caused by the migrant strains were recently observed as late blight reemerged as a serious threat to potato production worldwide $(2,14,15)$.

The molecular basis of host specificity of $P$. infestans is poorly understood (25). To date, no late blight resistance gene of Solanum spp. or race-specific avirulence gene of $P$. infestans has been isolated. However, in recent years, a family of extracellular protein elicitors termed elicitins has been identified, and evidence has accumulated for a role of these molecules in delimiting the host range of Phytophthora spp. $(21,28,48)$. Elicitins are highly conserved $10-\mathrm{kDa}$ proteins that are secreted by all tested Phytophthora and Pythium spp. $(22,29,34)$. Elicitins induce defense responses including HR on a restricted number of plants, specifically Nicotiana spp. in the Solanaceae family $(6,30)$. Responsive plants, such as Nicotiana spp., are thought to display higher levels of resistance to elicitin-producing Phytophthora isolates than to elicitin-deficient ones. Direct experimental support of this hypothesis has recently been achieved. $P$. infestans strains deficient in the production of the major secreted elicitin INF1 were engineered by transformation with antisense infl gene constructs. In contrast to the wild-type and control transformants, these infl silenced transformants-induced disease lesions when inoculated on $N$. benthamiana, suggesting that INF1 elicitin is an avirulence factor (28).

In a recent study, we examined the potential role of INF1 as an elicitor in interactions between $P$. infestans and Solanum spp. (27). Eighteen lines, representing eight Solanum spp. with various levels of resistance to $P$. infestans, were found not to respond to an Escherichia coli-expressed INF1. Therefore, within the tested set of Solanum spp., resistance to P. infestans does not appear to be mediated by a defense response elicited by INF1. However, considering the extraordinary diversity noted in the genus Solanum and the extensive period of association between several Solanum spp. and $P$. infestans $(41,47)$, response to INF1 may occur in yet unidentified Solanum genotypes. 
In this study, we examine the variation in production of extracellular INF1 by $P$. infestans. A large set of isolates was examined, and five isolates collected in 1976 and 1977 from infected potatoes in East Germany (the former German Democratic Republic) were found to be deficient in INF1 production. We used amplified fragment length polymorphism (AFLP) DNA fingerprinting to reconstruct the evolution of the loss of INF1 production in $P$. infestans populations. The occurrence of the infl gene and infl mRNA was also examined in representative isolates. Hypothetical interpretations of the evolution of $P$. infestans lineages deficient in the production of the protein elicitor are discussed.

\section{MATERIALS AND METHODS}

Phytophthora isolates and culture conditions. The various $P$. infestans isolates used in this study are listed in Table 1, along with their geographic origin, mating type, original host, and RG57 DNA fingerprint pattern. The 1976 and 1977 isolates from East Germany are probably identical to those described by Dagget et al. $(9,10,36)$, because they were obtained from similar sources. Strains were routinely cultured on rye agar medium supplemented with $2 \%$ sucrose (7). For INF1 elicitin production, culture filtrates were harvested following growth for 3 to 4 weeks at $18^{\circ} \mathrm{C}$ in still cultures in the synthetic medium described by Kamoun et al. (29).

Sodium dodecyl sulfate-polyacrylamide gel electrophoresis (SDS-PAGE). Culture filtrates were subjected to Tris-tricine SDSPAGE as described elsewhere $(37,38)$. Following electrophoresis, gels were silver-stained following the method of Merril et al. (33).

DNA manipulations. Total DNA of $P$. infestans was isolated from mycelium grown in liquid culture as previously described (35).

TABLE 1. Production of INF1 elicitin by Phytophthora infestans isolates from 15 countries in five continents ${ }^{\mathrm{a}}$

\begin{tabular}{|c|c|c|c|c|c|c|c|}
\hline Country & Accession \# & Year & Mating type & Host & Fingerprint pattern ${ }^{b}$ & Genotype $^{\mathrm{c}}$ & $\mathrm{INF}^{\mathrm{d}}$ \\
\hline \multicolumn{8}{|l|}{ Africa } \\
\hline Rwanda & RWA02 & $\ldots$ & A1 & Potato & 1110101001001101011111011 & Other & + \\
\hline Rwanda & RWA04 & 1985 & A1 & Potato & 1011101011001101000110011 & US-1 & + \\
\hline Rwanda & RWA08 & 1984 & A1 & Potato & 1110111011001101011111011 & Other & + \\
\hline Uganda & UG-3 & 1996 & $\ldots$ & Tomato & $\ldots$ & $\ldots$ & + \\
\hline Uganda & UG-7 & 1996 & $\ldots$ & Tomato & $\ldots$ & $\ldots$ & + \\
\hline Uganda & UG-8 & 1996 & $\ldots$ & Tomato & $\ldots$ & $\ldots$ & + \\
\hline \multicolumn{8}{|l|}{ Asia } \\
\hline Philippines & PH9001 & 1990 & A1 & $\ldots$ & 1011101011001101000110011 & US-1 & + \\
\hline Philippines & PH9002 & 1990 & A1 & $\ldots$ & 1011101011001101000110011 & US-1 & + \\
\hline Philippines & PH9055 & 1990 & A1 & $\ldots$ & 1011101011001101000110011 & US-1 & + \\
\hline \multicolumn{8}{|l|}{ Europe } \\
\hline Denmark & DE9061 & 1990 & $\ldots$ & Potato & $\ldots$ & $\ldots$ & + \\
\hline Denmark & DE9062 & 1990 & $\ldots$ & Potato & $\ldots$ & $\ldots$ & + \\
\hline Denmark & DE9063 & 1990 & $\ldots$ & Potato & $\ldots$ & $\ldots$ & + \\
\hline Germany (East) & DDR7601 & 1976 & A1 & Potato & 1011101011001101000110011 & US-1 & + \\
\hline Germany (East) & DDR7602 & 1976 & A1 & Potato & 1011101011001101000110011 & US-1 & - \\
\hline Germany (East) & DDR7603 & 1976 & A1 & Potato & 1011101011001101000110011 & US-1 & - \\
\hline Germany (East) & DDR7604 & 1976 & A1 & Potato & 1011101011001101000110011 & US-1 & - \\
\hline Germany (East) & DDR7605 & 1976 & A1 & Potato & 1011101011001101000110011 & US-1 & - \\
\hline Germany (East) & DDR7702 & 1977 & A1 & Potato & 1011101011001101000110011 & US-1 & - \\
\hline Germany (East) & DDR7704 & 1977 & A1 & Potato & 1011101011001101000110011 & US-1 & + \\
\hline Germany (East) & DDR8001 & 1980 & A1 & Potato & 1000100001011101000110011 & Other & + \\
\hline Germany (East) & GE900068 & 1990 & A1 & Potato & $\ldots$ & $\ldots$ & + \\
\hline Germany (East) & GE900071 & 1990 & A1 & Potato & $\ldots$ & $\ldots$ & + \\
\hline Germany (East) & GE900079 & 1990 & A1 & Potato & $\ldots$ & $\ldots$ & + \\
\hline Germany (East) & GE900083 & 1990 & A1 & Potato & $\ldots$ & $\ldots$ & + \\
\hline Germany (East) & GE900089 & 1990 & A1 & Potato & $\ldots$ & $\ldots$ & + \\
\hline Germany (East) & GE900090 & 1990 & A1 & Potato & $\ldots$ & $\ldots$ & + \\
\hline Germany (East) & GE900091 & 1990 & A1 & Potato & $\ldots$ & $\ldots$ & + \\
\hline Germany (East) & GE900093 & 1990 & A1 & Potato & $\ldots$ & $\ldots$ & + \\
\hline Germany (East) & GE900098 & 1990 & A1 & Potato & $\ldots$ & $\ldots$ & + \\
\hline Germany (West) & GER7401 & 1974 & A1 & Potato & 1011101011001101000110011 & US-1 & + \\
\hline Germany (West) & GER8451 & 1984 & A1 & Potato & 1011101011001101000110011 & US-1 & + \\
\hline Germany (West) & GER8501 & 1985 & A1 & Potato & 1011101011001101000110011 & US-1 & + \\
\hline Germany (West) & GER8601 & 1986 & A1 & Potato & 1011101011001101000110011 & US-1 & + \\
\hline Germany (West) & GER8603 & 1986 & A1 & Potato & 1011101011001101000110011 & US-1 & + \\
\hline Italy & IT8001 & 1980 & A1 & Tomato & 1011101011001101000110011 & US-1 & + \\
\hline Netherlands & 66006 & 1966 & A1 & Potato & 1011101011001101000110011 & US-1 & + \\
\hline Netherlands & 68308 & 1968 & A1 & Potato & 1011101011001101000110011 & US-1 & + \\
\hline Netherlands & 70001 & 1970 & A1 & Potato & 1011101011001101000110011 & US-1 & + \\
\hline Netherlands & 74001 & 1974 & A1 & Potato & 1011101011001101000110011 & US-1 & + \\
\hline Netherlands & 80029 & 1980 & A1 & Potato & 010-100001001101000101011 & Other & + \\
\hline Netherlands & 81197 & 1981 & A2 & Potato & $110-101000001101011111011$ & Other & + \\
\hline Netherlands & 84215 & 1984 & A1 & Potato & $111-111011001100011110011$ & Other & + \\
\hline Netherlands & 85005 & 1985 & A1 & Potato & $101-111001001101000111011$ & Other & + \\
\hline Netherlands & 86004 & 1986 & A1 & Potato & $111-111111001101011110011$ & Other & + \\
\hline Netherlands & 86063 & 1986 & $\mathrm{~A} 2$ & Tomato & $100-101000001101011111011$ & Other & + \\
\hline Netherlands & 86061 & 1986 & $\mathrm{~A} 2$ & Tomato & $100-101000001101011111011$ & Other & + \\
\hline \multirow[t]{2}{*}{ Netherlands } & 87030 & 1987 & $\mathrm{~A} 2$ & Potato & $111-101001001100011111011$ & Other & + \\
\hline & & & & & & \multicolumn{2}{|c|}{ (continued on the next page) } \\
\hline
\end{tabular}

a $\ldots=$ not available.

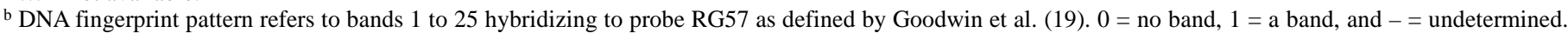
Note that band 4 could not be determined unambiguously for some isolates and was, therefore, excluded from the cluster analysis shown in Figure 1.

c Genotype designations are as indicated in Goodwin et al. (18,20).

$\mathrm{d}+$ refers to the production of INF1 and - to the absence of INF1 in culture filtrate as determined by SDS-PAGE. Examples are shown in Figure 4C. 
Alkaline DNA transfer to Hybond N+ (Amersham, Arlington Heights, IL) and Southern hybridizations were performed at $65^{\circ} \mathrm{C}$ as described elsewhere $(3,37)$. Filters were washed at $55^{\circ} \mathrm{C}$ in $0.5 \times \mathrm{SSC}$ (75 mM NaCl and $7.5 \mathrm{mM}$ sodium citrate). Note that the size of the $P$. infestans BamHI fragment containing the infl gene was more accurately determined to 2.3 kilobase (kb) and not $3.2 \mathrm{~kb}$ as previously reported (27).

RNA manipulations. Total RNA from $P$. infestans was isolated using the guanidine hydrochloride extraction method (32). For RNA blot analyses, 10 to $15 \mathrm{mg}$ of total RNA was denatured at $50^{\circ} \mathrm{C}$ in $1 \mathrm{M}$ glyoxal, $50 \%$ dimethyl sulfoxide (DMSO), and $10 \mathrm{mM}$ sodium phosphate, electrophoresed, and transferred to Hybond N+ membranes $(3,37)$. Hybridizations were conducted at $65^{\circ} \mathrm{C}$ in $0.5 \mathrm{M}$ sodium phosphate buffer, 7\% SDS, and $1 \mathrm{mM}$ EDTA. Filters were washed at $55^{\circ} \mathrm{C}$ in $0.5 \times \mathrm{SSC}(75 \mathrm{mM} \mathrm{NaCl}$ and $7.5 \mathrm{mM}$ sodium citrate).
DNA and RNA blot hybridization probes. Gel-purified DNA fragments containing the full infl cDNA insert from pFB7 (27) or the actA gene from pSTA31 (42) were used as probes and radiolabelled with $\alpha-{ }^{32} \mathrm{P}-\mathrm{dATP}$ using a random primer labeling kit (Gibco BRL, Bethesda, MD).

Restriction fragment length polymorphism (RFLP) and AFLP DNA fingerprinting. RG57 DNA fingerprinting patterns (bands 1 to 25) were compiled from several published sources and databases from our laboratory and the laboratory of W. E. Fry (Cornell University). RG57 band 4 was omitted from the analysis, because it was scored differently by independent laboratories. AFLP fingerprints were generated as described by Vos et al. (46) using experimental conditions that generate highly informative fingerprints of $P$. infestans (44). Briefly, total DNA was digested with the restriction enzymes EcoRI and MseI, after which adapters were ligated to the DNA fragments. The adapter fitting the EcoRI restriction

TABLE 1. (continued from preceding page)

\begin{tabular}{|c|c|c|c|c|c|c|c|}
\hline Country & Accession \# & Year & Mating type & Host & Fingerprint pattern ${ }^{\mathrm{b}}$ & Genotype $^{c}$ & $\mathrm{INF} 1^{\mathrm{d}}$ \\
\hline \multicolumn{8}{|l|}{ Europe (continued) } \\
\hline Netherlands & 88069 & 1988 & A1 & Tomato & $\ldots$ & $\ldots$ & + \\
\hline Netherlands & 88074 & 1988 & A1 & Tomato & $101-101001001100111110011$ & Other & + \\
\hline Netherlands & 88133 & 1988 & A2 & Potato & $101-101101001100011111011$ & Other & + \\
\hline Netherlands & 88034 & 1988 & $\mathrm{~A} 2$ & Tomato & $100-100100001101011111011$ & Other & + \\
\hline Netherlands & 89038 & 1989 & A2 & Potato & $\ldots$ & $\ldots$ & + \\
\hline Netherlands & 89148 & 1989 & A1 & Potato & $111-101001001100111111011$ & Other & + \\
\hline Netherlands & 90210 & 1990 & A1 & Potato & $\ldots$ & $\ldots$ & + \\
\hline Netherlands & 90209 & 1990 & A1 & Potato & $110-100001001101000111011$ & Other & + \\
\hline Netherlands & 90128 & 1990 & A2 & Potato & $100-100011001100000110011$ & Other & + \\
\hline Netherlands & 91014 & 1991 & A1 & Potato & $101-111001001101011111011$ & Other & + \\
\hline Netherlands & 91011 & 1991 & $\mathrm{~A} 2$ & Potato & $101-101001001101011111001$ & Other & + \\
\hline Netherlands & 91001 & 1991 & A2 & Potato & $101-101100001101100110011$ & Other & + \\
\hline Netherlands & 91002 & 1991 & A2 & Potato & $101-101111001101000110011$ & Other & + \\
\hline Netherlands & 95001 & 1995 & $\ldots$ & Potato & $\ldots$ & $\ldots$ & + \\
\hline Netherlands & 95002 & 1995 & $\ldots$ & Potato & $\ldots$ & $\ldots$ & + \\
\hline Netherlands & 95003 & 1995 & $\ldots$ & Potato & $\ldots$ & $\ldots$ & + \\
\hline Netherlands & 95004 & 1995 & $\ldots$ & Potato & $\ldots$ & $\ldots$ & + \\
\hline Netherlands & 95005 & 1995 & $\ldots$ & Potato & $\ldots$ & $\ldots$ & + \\
\hline Netherlands & 95006 & 1995 & $\ldots$ & Potato & $\ldots$ & $\ldots$ & + \\
\hline Netherlands & 95007 & 1995 & $\ldots$ & Potato & $\ldots$ & $\ldots$ & + \\
\hline Netherlands & 95008 & 1995 & $\ldots$ & Potato & $\ldots$ & $\ldots$ & + \\
\hline Netherlands & 95009 & 1995 & $\ldots$ & Potato & $\ldots$ & $\ldots$ & + \\
\hline Netherlands & 95010 & 1995 & $\ldots$ & Potato & $\ldots$ & $\ldots$ & + \\
\hline Poland & POL8402 & 1984 & $\ldots$ & Potato & $\ldots$ & $\ldots$ & + \\
\hline Poland & PO850020 & 1985 & A1 & Potato & $\ldots$ & $\ldots$ & + \\
\hline Poland & PO860019 & 1986 & A1 & Potato & $\ldots$ & $\ldots$ & + \\
\hline Poland & PO860021 & 1986 & A1 & Potato & $\ldots$ & $\ldots$ & + \\
\hline Poland & PO880041 & 1988 & A1 & Potato & $\ldots$ & $\ldots$ & + \\
\hline Poland & PO880052 & 1988 & A1 & Potato & $\ldots$ & $\ldots$ & + \\
\hline Romania & ROM1 & $\ldots$ & $\ldots$ & $\ldots$ & $\ldots$ & $\ldots$ & + \\
\hline Spain & SP9665 & 1996 & $\ldots$ & Potato & $\ldots$ & $\ldots$ & + \\
\hline Spain & SP9669 & 1996 & $\ldots$ & Potato & $\ldots$ & $\ldots$ & + \\
\hline Spain & SP9670 & 1996 & $\ldots$ & Potato & $\ldots$ & $\ldots$ & + \\
\hline Spain & SP9671 & 1996 & $\ldots$ & Potato & $\ldots$ & $\ldots$ & + \\
\hline Spain & SP9696 & 1996 & $\ldots$ & Potato & $\ldots$ & $\ldots$ & + \\
\hline Spain & SP9698 & 1996 & $\ldots$ & Potato & $\ldots$ & $\ldots$ & + \\
\hline Spain & SP9699 & 1996 & $\ldots$ & Potato & $\ldots$ & $\ldots$ & + \\
\hline Spain & SP9600 & 1996 & $\ldots$ & Potato & $\ldots$ & $\ldots$ & + \\
\hline United Kingdom & UK7818 & 1978 & A1 & Potato & 1011101011001101000110011 & US-1 & + \\
\hline United Kingdom & UK7225 & 1972 & A1 & Potato & 1011101011001101000110011 & US-1 & + \\
\hline \multicolumn{8}{|l|}{ North America } \\
\hline United States & USA-128 & 1982 & A1 & Potato & 1011101011001101000110011 & US-1 & + \\
\hline United States & BIN-16 & 1992 & A1 & $\ldots$ & 1011111001001100010110011 & US-6 & + \\
\hline United States & W193-13 & 1993 & A1 & Potato & 1011101011001101000110011 & US-1 & + \\
\hline United States & ME93-2A & 1993 & A2 & Potato & 1001100001001101000110111 & US-8 & + \\
\hline United States & US940478 & 1994 & A1 & $\ldots$ & $\ldots$ & $\ldots$ & + \\
\hline United States & BG-8 & $\ldots$ & $\mathrm{A} 2$ & $\ldots$ & 1001100001001101010110011 & US-7 & + \\
\hline Mexico & TV545 & $\ldots$ & A1 & Potato & 1000100001001101011110001 & Other & + \\
\hline Mexico & TV580 & $\ldots$ & A1 & Potato & 1010101101001101000110111 & Other & + \\
\hline Mexico & TV618 & $\ldots$ & $\mathrm{A} 2$ & Potato & 1000100001001101000110011 & Other & + \\
\hline \multicolumn{8}{|l|}{ South America } \\
\hline Peru & PE807 & 1985 & A1 & Potato & 1011101011001101000110011 & US-1 & + \\
\hline Peru & PE821 & 1984 & A1 & Potato & $101-101011001101000111011$ & Other & + \\
\hline Unknown & 46210 & 1946 & $\ldots$ & $\ldots$ & $\ldots$ & $\ldots$ & + \\
\hline Unknown & 51366 & 1951 & A1 & Potato & $101-101000001101000110011$ & Other & + \\
\hline
\end{tabular}


site was 5'-CTCGTAGACTGCGTACC/CTGACGCATGGTTAA$5^{\prime}$, and the adapter fitting the MseI restriction site was 5'-GACGATGAGTCCTGAG/TACTCAGGACTCAT-5' ${ }^{\prime}$. A subset of the restriction fragments was amplified in two subsequent polymerase chain reaction (PCR) amplification steps. In the first PCR, primers were used that are homologous to the adapter sequence, the restriction site, and one additional selective base at the $3^{\prime}$ end (5'-GACTGCGTACCAATTCA for the EcoRI site and 5'-ATGAGTCCTGAGTAAC for the MseI site). In the second PCR, both the EcoRI and the $M s e I$ primers contained two selective bases. The EcoRI restriction site primer was $5^{\prime}$-GACTGCGTACCAATTCAC, and the $M s e I$ restriction site primers were 5'-ATGAGTCCTGAGTAACA, - $C C$, - $C G,-C T$. In the second PCR, the EcoRI primer was labeled at the $5^{\prime}$ end with ${ }^{33} \mathrm{P}$ and, after electrophoresis on $4 \%$ denaturing polyacrylamide gels, PCR fragments were detected by autoradiography. More experimental details can be found in Vos et al. (46) and van der Lee et al. (44).

Phenetic and phylogenetic analyses. A matrix of simple genetic distance based on RFLP data was constructed using the software

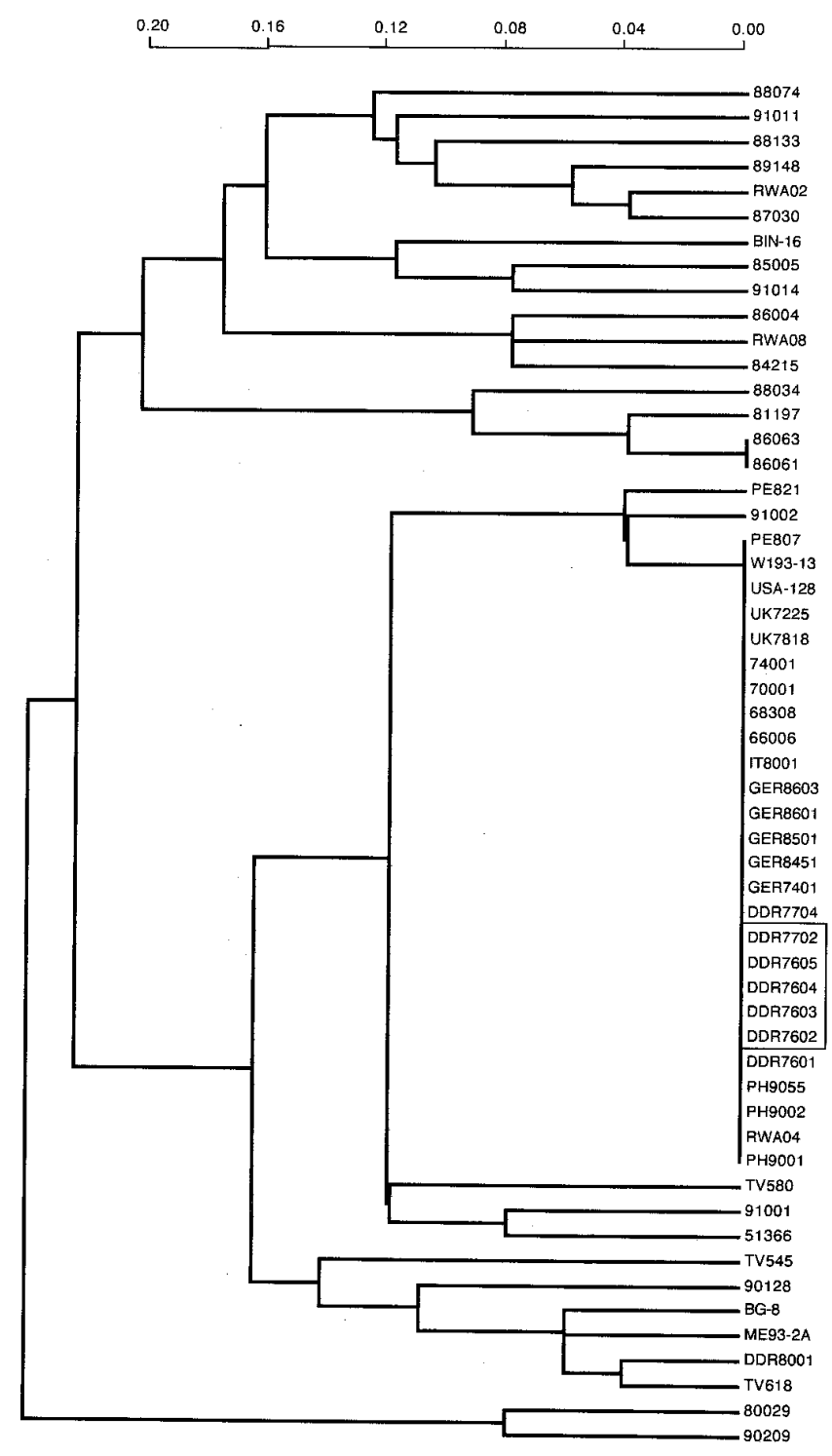

Fig. 1. Phenetic tree of 55 Phytophthora infestans isolates used in this study based on RG-57 restriction fragment length polymorphism fingerprint markers. The tree was generated using unweighted pair group method with arithmetic means clustering of a simple genetic distance matrix. The five East German isolates that do not produce INF1 are shown in a box. The scale represents genetic similarity distance.
NTSYS-pc 1.7 (F. J. Rohlf, Exeter Software, New York). The matrix was used to generate an unweighted pair group method with arithmetic means (UPGMA) phenogram using the PHYLIP 3.5c software package (J. Felsenstein, University of Washington, Seattle). Maximum-parsimony analysis of AFLP fingerprinting data was conducted using the PAUP 3.1 (phylogenetic analysis using parsimony) software (D. L. Swofford, Illinois Natural History Survey, Champaign). Heuristic search using 1,000 bootstrap replicates was conducted with branch swapping by tree bisectionreconnection (TBR).

\section{RESULTS}

Most $P$. infestans isolates produce INF1. We surveyed 102 isolates of $P$. infestans from 15 countries and five continents for INF1 elicitin production by PAGE of crude culture filtrates. The production of INF1 was almost ubiquitous in P. infestans; PAGE of culture filtrates from 97 isolates $(95 \%)$ showed a $10-\mathrm{kDa}$ band that comigrates with authentic elicitins (Table 1). These INF1 producers include both $\mathrm{A} 1$ and $\mathrm{A} 2$ mating type isolates from potato and tomato, suggesting no correlation between INF1 production and mating type or host of origin. In contrast to these 97 isolates, PAGE of culture filtrates from the remaining five isolates consistently failed to reveal a $10-\mathrm{kDa}$ band, suggesting that these $P$. infestans isolates do not secrete INF1.

Absence of INF1 production is restricted to East German populations of the US-1 genotype. Phenetic analysis, using UPGMA clustering calculated from RFLP data obtained previously with the multilocus DNA fingerprint probe RG57, was conducted with a set of 55 isolates tested for INF1 production. As shown in Figure 1, the resulting phenogram indicates that a diverse range of $P$. infestans genotypes was tested in this study. Despite this diversity, absence of INF1 production was noted only in isolates with the US-1 genotype. Interestingly, even though 26 P. infestans US-1 isolates from nine countries were tested, all five isolates that fail to produce INF1 (DDR7602, DDR7603, DDR7604, DDR7605, and DDR7702) were collected in East German potato fields in 1976 and 1977 (Table 1). These results suggest that INF1 nonproducing mutant(s) arose within the US-1 clonal populations of East Germany. Furthermore, isolates of diverse genotypes collected in the eastern part of Germany in 1980 and 1990 produce normal levels of INF1, suggesting that the INF1-nonproducing populations were displaced in the 1980 s by new INF1producing migrant strains.

Independent loss of production of INF1 in the $P$. infestans clonal lineage US-1. To identify sublineages within the US-1 clonal lineage, we used AFLP DNA fingerprinting to generate additional molecular markers. A set of 18 European US-1 isolates, including the five INF1 deficient isolates and two 1990 German isolates of different genotypes, were tested. Similar to RFLP analyses, $P$. infestans isolates of the US-1 genotype showed distinct AFLP patterns and can be easily distinguished from isolates of different genotypes (Fig. 2). To determine the number of evolutionary events that led to loss of INF1 production within the US-1 clonal lineage, a total of 146 polymorphic AFLP bands were scored for all 20 isolates. Phylogenetic analysis was conducted using the maximum-parsimony software PAUP 3.1. Of the 146 examined bands, 94 were informative in the parsimony analysis and 49 were polymorphic among the 18 US- 1 isolates. A total of 1,000 bootstrap replications were conducted to determine the significance of the branches obtained in the shortest tree (Fig. 3). Within the US-1 lineage, three significant branches (>50\%) were identified. One contains isolates from Germany and the Netherlands. The other two contain isolates from Germany and the United Kingdom, respectively. Additionally, four isolates from Germany, the Netherlands, and Italy did not significantly associate with any of the three branches. Interestingly, the five INF1-nonproducing isolates were split over at least three branches. 
This suggests that several mutations leading to loss of INF1 production occurred independently.

INF1-nonproducing isolates still retain the inf1 gene, but have little inf1 mRNA. We previously determined that in three $P$. infestans isolates with different genotypes the infl gene is localized in a conserved 2.3-kb BamHI fragment (27). To determine whether the isolates deficient in INF1 production still retain infl sequences, BamHI-digested total DNA from a representative set of 16 isolates of $P$. infestans was hybridized with a probe from the infl gene. A single hybridizing Bam $\mathrm{HI}$ band of 2.3-kb was observed in all examined isolates including the INF1-nonproducing isolates DDR7602 and DDR7702 (Fig. 4A and C). These results suggest that the BamHI fragment carrying the infl gene is highly conserved in $P$. infestans and that no gross alteration of the infl gene occurred in isolates deficient in INF1 production. To determine whether INF1 deficiency correlates with the absence of infl mRNA, total RNA was isolated from the same set of isolates and hybridized with the infl probe. All examined INF1producing isolates showed significant levels of infl mRNA, but little or no infl mRNA was detected in the nonproducing isolates DDR7602 and DDR7702 (Fig. 4B and C). Control hybridizations with a probe of the constitutively expressed actA gene showed that all lanes contained similar amounts of total RNA (Fig. 4B). Note that in the experiment shown in Figure 4, isolates GER8501 and GE900083 show lower levels of inf1 mRNA and INF1 protein than other producer isolates (Fig. 4B and $C$, lanes 6 and 15). However, in independent replicate experiments, both isolates produced higher levels of INF1 comparable to other INF1-producing isolates. In addition, repeated culturing of isolate DDR7602 revealed that trace amounts of infl mRNA and INF1 protein may occasionally be detected (Fig. 4B, lane 2).
Absence of INF1 production is not associated with the inability to form sporangia in vitro. Ritch and Daggett (36) reported that isolates from East Germany collected in the 1970s fail to sporulate when grown in vitro. We also noted that some of the INF1-nonproducing isolates, which are probably identical to Ritch and Daggett isolates, frequently fail to form sporangia when cultured on rye-sucrose medium. This raised the possibility that the lack of INF1 production noted in this study for some East German isolates was correlated to the lack of sporulation. To test this hypothesis, we carefully analyzed sporulation of the INF1-nonproducer DDR7602. This isolate is generally nonsporulating, but it occasionally forms sporulating sectors when grown on rye-sucrose medium. Following four sequential subcultures of mycelium from both sporulating and nonsporulating sectors, cultures stable for either phenotype were obtained. PAGE of culture filtrates from both sporulating and nonsporulating derivatives of DDR7602 failed to show a $10-\mathrm{kDa}$ band (data not shown), suggesting that deficiency in INF1 production by DDR7602 is not correlated to its inability to produce sporangia.

\section{DISCUSSION}

The extracellular elicitins of Phytophthora act as avirulence factors that restrict the host range of the pathogen by triggering defense responses in sensitive plants $(28,48)$. In this paper, we investigate variation in the production of INF1, the major secreted elicitin of $P$. infestans. Isolates from 15 countries in five continents representing a wide array of genetic diversity were tested for production of INF1 (Table 1, Fig. 1). Similar to other Phytophthora spp. (29), most $P$. infestans isolates (95\%) produce large amounts of elicitin when cultured in vitro. No correlation between INF1 production and mating type or host of origin (potato or tomato)

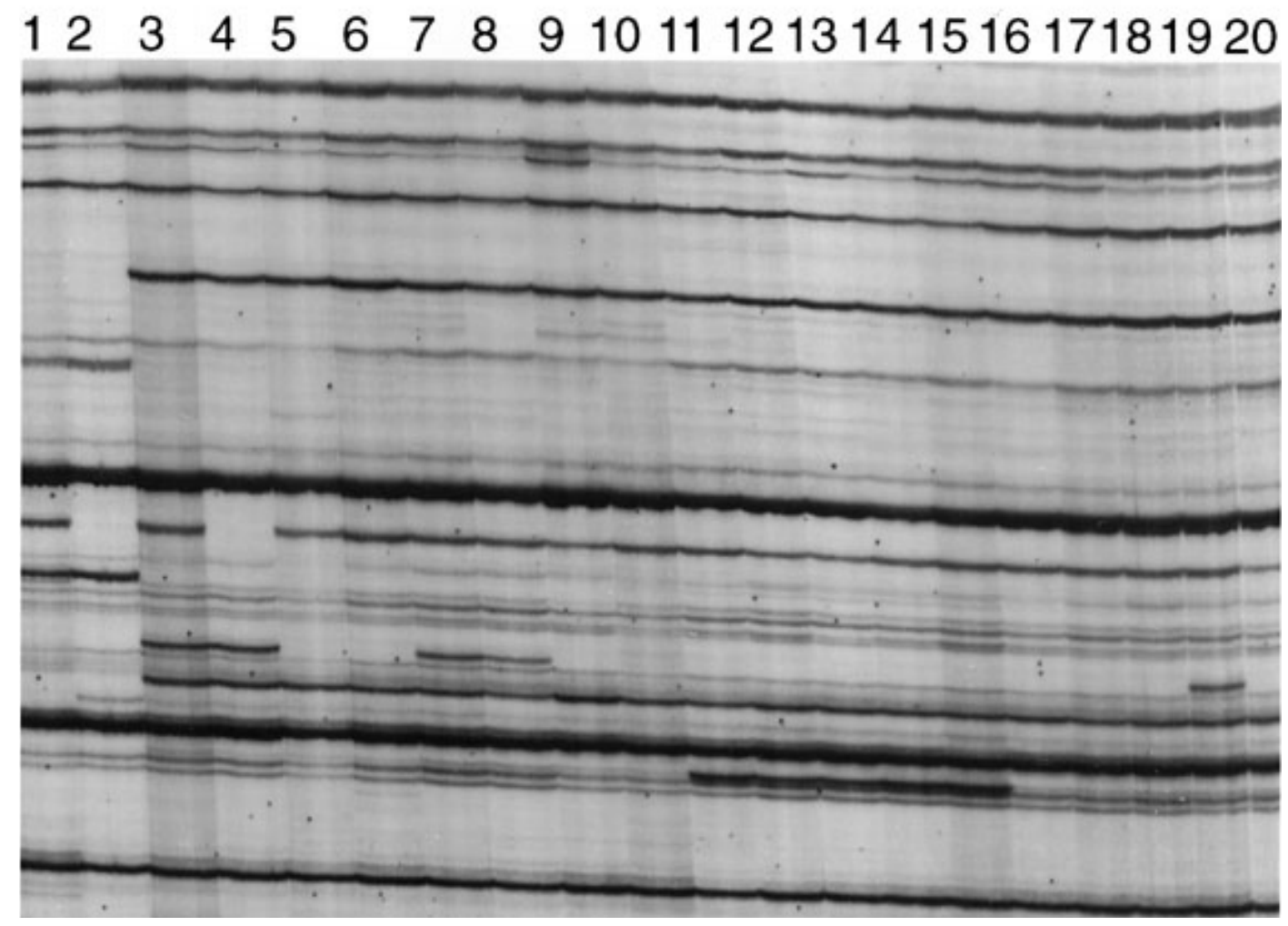

Fig. 2. Section of autoradiograph showing amplified fragment length polymorphism (AFLP) DNA fingerprints of Phytophthora infestans isolates as follows: lane 1, GE900089; lane 2, GE900083; lane 3, UK7818; lane 4, UK7225; lane 5, GER8501; lane 6, GER8451; lane 7, NL68308; lane 8, NL66006; lane 9, GER8601; lane 10, GER7401; lane 11, DDR7605; lane 12, DDR7604; lane 13, DDR7603; lane 14, DDR7602; lane 15, DDR7601; lane 16, GER8603; lane 17, IT8001; lane 18, NL74001; lane 19, NL70001; and lane 20, DDR7702. The AFLP DNA fingerprints shown here were generated with the primer combination GACTGCGTACCAATTCCAA, a primer fitting the EcoRI adapter and three selective bases, and ATGAGTCCTGAGTAACG, a primer fitting the $M s e$ I adapter and two selective bases. Approximately $20 \%$ of the total length of the lanes is shown. 
was noted. The absence of INF1 production was noted only in 5 out of 102 P. infestans isolates, DDR7602, DDR7603, DDR7604, DDR7605, and DDR7702. All these isolates were collected in 1976 to 1977 from potato fields in East Germany. Since multiple isolates of similar origin fail to produce INF1, it is unlikely that this trait arose in the lab as a result of a rare mutation. Additionally, all other isolates tested including those collected 50 years ago produce normal levels of INF1, making it unlikely that continuous in vitro culturing frequently gives rise to INF1 nonproducers. Therefore, we assume that the absence of INF1 production noted in vitro reflects a frequently occurring phenotype (71\%) among East German isolates of $P$. infestans from the mid 1970s.

Of the isolates tested in this study for production of INF1, 26 bear a DNA fingerprint pattern diagnostic of US-1, the clonal lineage that dominated the fields in Europe until the 1980s $(12,18)$. All five INF1 nonproducers identified belong to this clonal lineage. Even though US-1 isolates from nine countries in five continents were tested, all nonproducers originate from a restricted geographic area, East Germany. Interestingly, US-1 isolates from neighboring countries such as West Germany (Federal Republic of Germany) and Poland produce normal levels of INF1.

Since $P$. infestans isolates of the US-1 genotype have propagated clonally by asexual reproduction, it is possible to reconstruct the phylogeny of these isolates given enough polymorphic molecular markers. To determine whether all five INF1 nonproducers arose from one common mutant ancestor or whether loss of INF1 production occurred repeatedly in $P$. infestans, we conducted a phylogenetic analysis on a set of 18 European US-1 isolates using

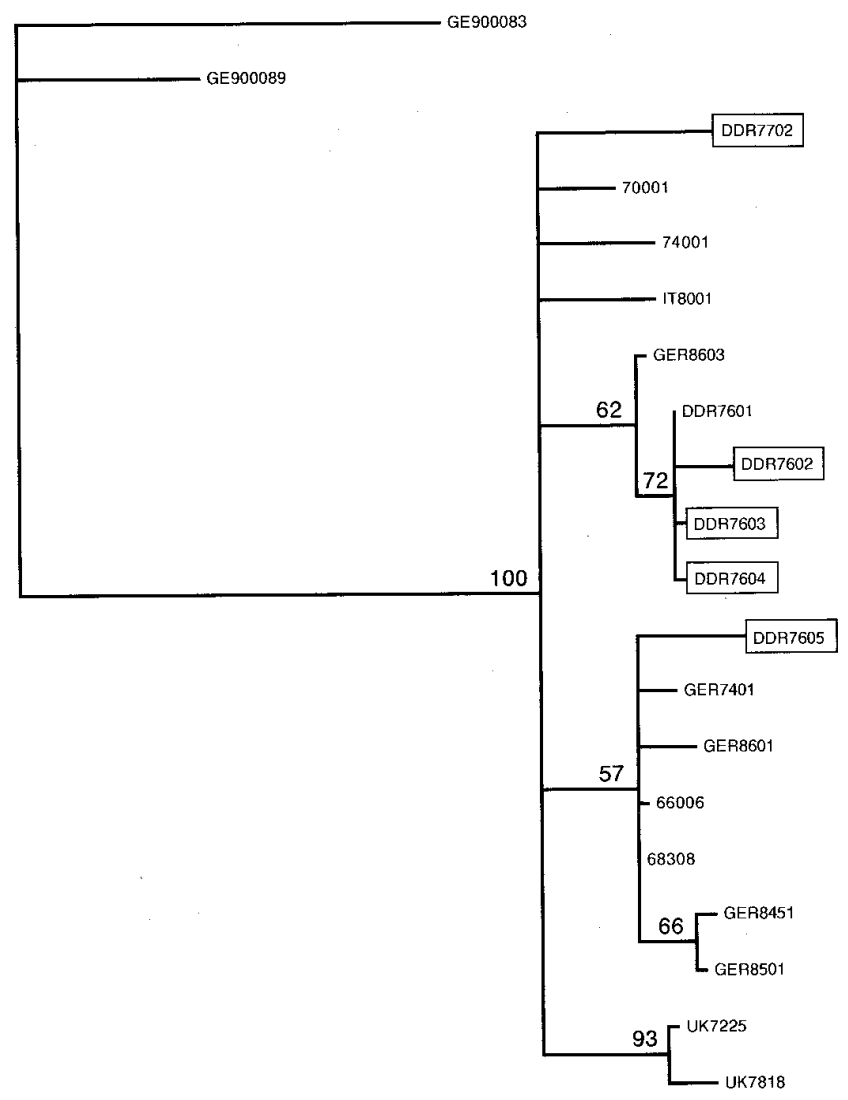

Fig. 3. Strict consensus tree of 18 European Phytophthora infestans isolates of the US-1 genotype inferred by bootstrap analysis of 146 amplified fragment length polymorphism fingerprint markers. Significant bootstrap values (above 50\%) from 1,000 replications are indicated at the nodes. Two 1990 isolates from the eastern part of Germany, GE900083 and GE 900089, were used as outgroups. The five East German isolates that do not produce INF1 are shown in boxes. markers generated by AFLP DNA fingerprinting (Figs. 2 and 3). A phylogenetic tree was generated using parsimony analysis, and 14 of the tested isolates were found to belong to three statistically significant branches within the US-1 lineage. Interestingly, the INF1-nonproducing isolates were split over at least three branches of the tree, suggesting that loss of INF1 production occurred on multiple occasions within the US-1 lineage. Such a pattern of rapid evolution is reminiscent of the evolution of virulence and pathogenicity in Phytophthora spp. $(13,17,20)$. However, alternative interpretations of the phylogenetic reconstruction of the European US-1 isolates are possible. For example, a high rate of mutation at the infl locus could have resulted in reversion to the INF1-producing phenotype in strains closely related to the nonproducers. In addition, it can not be excluded that atypical genetic mechanisms such as mitotic recombination or somatic fusion between different isolates may have led to aberrant changes in INF1 production. However, as long as the exact nature of the mutated INF1 phenotype in East German isolates is unknown, we assume the simplest interpretation of the phylogenetic tree. We favor the hypothesis that loss of INF1 production occurred independently in the three different sublineages and that the absence of INF1 production may have contributed some fitness gain to East German US-1 populations of $P$. infestans. A consequence related to this hypothesis is that INF1 nonproducers might be more virulent than INF1 producers on particular plant genotypes cultivated in East Germany in the 1970s. Selective pressure would have resulted in increase in frequency of INF1-nonproducing $P$. infestans isolates. We plan to test this by examining a large set of potato lines cultivated in East Germany in the 1970s for response to the INF1 elicitor and resistance to INF1producing and -nonproducing strains.

Modern analyses of population genetics of Phytophthora using variation in isozymes and RFLP markers resulted in great insight into the population structures and macro-evolution of several species $(12,13,16,18,20,49)$. However, the levels of analysis obtained using these markers remain limited, particularly in populations showing little polymorphism. We have previously exploited the AFLP DNA fingerprinting technique to generate the first high-resolution genetic map of $P$. infestans (44). In this study, we demonstrated that this technique could also be useful in achieving fine levels of genetic analysis of $P$. infestans populations. We identified a total of 49 polymorphic AFLP bands in a set of 18 US-1 isolates of $P$. infestans with no known isozyme or RFLP polymorphisms. With the advent of such a powerful fingerprinting technique, routine high-resolution analyses can now be achieved in population genetic studies of Phytophthora.

Virulent races of fungal and bacterial pathogens are generally defined by their failure to express particular avirulence genes (11, $31,39)$. In several cases, this phenotype is associated with the absence of DNA sequences homologous to the avirulence gene in the virulent strain $(43,45)$. Alternatively, nonfunctional recessive alleles of the avirulence gene may occur in the virulent strain $(23,24)$. In $P$. parasitica, which secretes the elicitin PARA1, virulent, PARA1nonproducing strains retain elicitin genes, but in one isolate, no PARA1 mRNA was detected (26). Similarly, in the two P. infestans INF1-nonproducing strains examined in this study, infl gene sequences were present, but little or no infl mRNA was detected (Fig. 4). Genetic analyses and transformation of tagged infl genes in the various backgrounds will help determine whether the inability to produce INF1 in $P$. infestans results from cis-acting mutations in infl or from trans-acting mutations in genes encoding regulatory proteins.

Apart from their ability to elicit defense responses in plants, the intrinsic role of elicitins in the biology of Phytophthora remains unknown. Based on their abundant secretion and primary amino acid structure, elicitins have been proposed to function as structural proteins $(40,48)$. Expression studies of the infl gene of $P$. infestans revealed that the highest levels of infl mRNA occurred in heavily sporulating mycelium, whether in vitro or in planta (27). These 
observations, along with the trace amounts of infl mRNA and INF1 protein that were occasionally detected in DDR7602, raised the possibility that the lack of INF1 production in East German isolates is correlated to the inability to produce sporangia noted in some of these isolates. However, stable cultures derived from sporulating sectors of the INF1-nonproducer isolate DDR7602 still did not secrete INF1, indicating that loss of INF1 production is not related to the morphological changes noted in some East German isolates.

Biotechnological engineering of potato to respond to INF1 is predicted to increase late blight resistance to INF1-producing strains of $P$. infestans $(27,48)$. Based on our survey (Table 1), most isolates of $P$. infestans including all tested isolates from recent epidemics in Europe (various NL-genotypes [12,49]) and North America (US-6, US-7, and US-8 genotypes $[17,18]$ ) produce INF1 and should, therefore, be avirulent on a potato line responsive to INF1. However, it remains to be determined whether such INF1-responsive potato lines will have durable late blight resistance. The identification of isolates deficient in INF1 suggests that $P$. infestans strains of the US-1 genotype can evolve loss of INF1 production and potentially gain virulence on elicitin-sensitive potato lines. Whether similar INF1-deficient races can readily evolve and reach high frequencies in sexual populations of $P$. infestans of various genotypes remains unclear. Experiments investigating potential fitness changes in INF1 mutants throughout the life cycle of $P$. infestans will address this question.

Even though races of $P$. infestans virulent on a wider range of plant genotypes have been described for 50 years (5), the molecular mechanisms underlying the evolution of new virulence traits in Phytophthora spp. remain unknown (25). Genetic crosses between $P$. infestans isolates with different virulence patterns suggest that avirulence to the $S$. demissum genes $R-2$ and $R-4$ is dominant (1), as documented in several plant-pathogenic fungi and bacteria. Previously, it was suggested that elicitins could act as dominant avirulence factors. Lack of elicitin production in P. parasitica was shown to correlate with increased virulence on sensitive plants (29). A re-

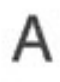

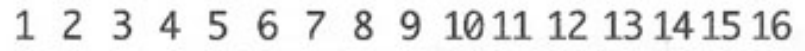

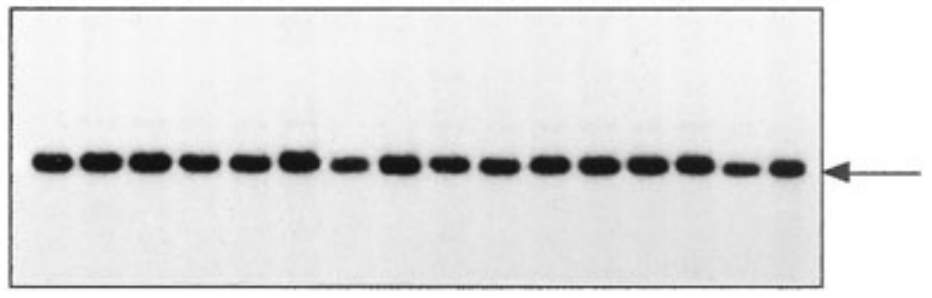

B
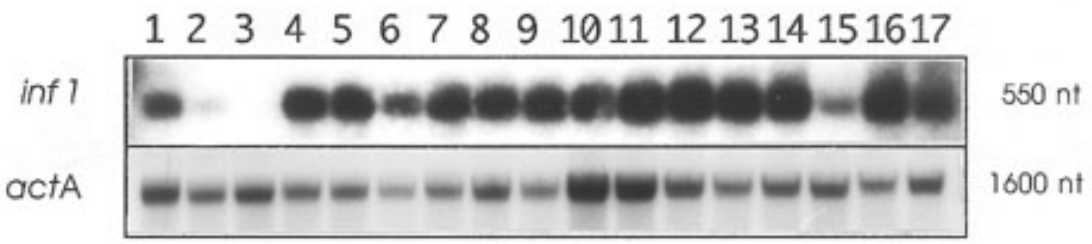

C

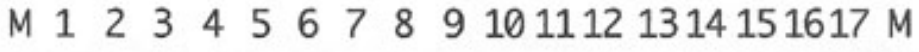

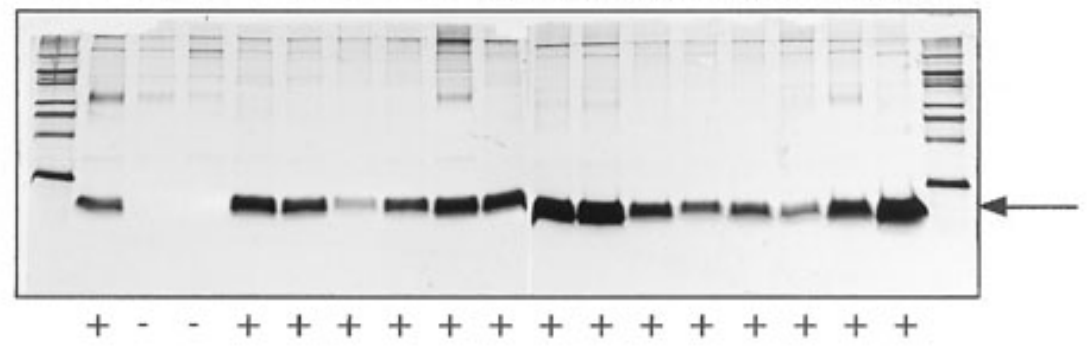

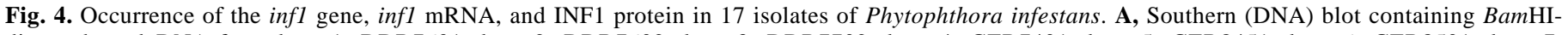

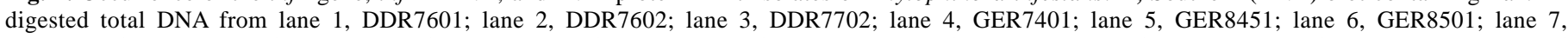

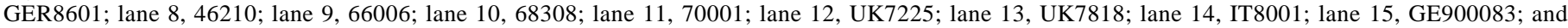

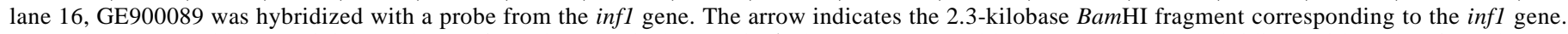

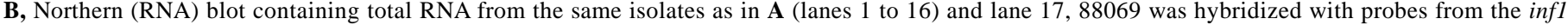

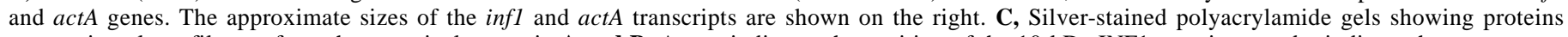

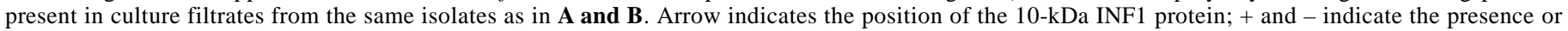
absence of INF1, respectively. 
cent finding in our laboratory strongly supports such an avirulence function for elicitins. We found that $P$. infestans strains engineered for INF1 deficiency have a broader host range, indicating that one of the molecular mechanisms underlying the evolution of a new race of $P$. infestans is based on mutations leading to loss of elicitin production (28). The results reported in this study, that INF1-nonproducing strains evolved independently in multiple lineages of $P$. infestans in a restricted geographic region (Table 1, Fig. 3), support this hypothesis. Future studies including the screening of potato germ plasm from the former East Germany for response to INF1 and comparative analyses of the virulence of INF1-producing and -nonproducing strains will help test this hypothesis.

\section{ACKNOWLEDGMENTS}

This project was supported by the Netherlands Technology Foundation (STW-SLW project 805-22-767), the European Commission (project AIR2-CT94-1263), and the Netherlands Association of Biotechnology Centers (ABON project II.1.3). We thank W. E. Fry, J. Tumwine, W. Waalkens, E. Iturritza, and E. Ritter for providing Phytophthora isolates; and $\mathrm{P}$. de Wit for critical reading of the manuscript.

\section{LITERATURE CITED}

1. Al-Kherb, S. M., Fininsa, C., Shattock, R. C., and Shaw, D. S. 1995. The inheritance of virulence of Phytophthora infestans to potato. Plant Pathol. 44:552-562.

2. Anonymous. 1996. Late blight: A global initiative. Int. Potato Center (CIP), Lima, Peru.

3. Ausubel, F. M., Brent, R., Kingston, R. E., Moore, D. D., Seidman, J. G., Smith, J. A., and Struhl, K. 1987. Current Protocols in Molecular Biology. J. Wiley \& Sons, New York.

4. Baker, B., Zambryski, P., Staskawicz, B., and Dinesh-Kumar, S. P. 1997. Signalling in plant-microbe interactions. Science 276:726-733.

5. Black, W., and Gallegy, M. E. 1957. Screening of Solanum species for resistance to Phytophthora infestans. Am. Potato J. 34:273-281.

6. Bonnet, P., Bourdon, E., Ponchet, M., Blein, J.-P., and Ricci, P. 1996. Acquired resistance triggered by elicitins in tobacco and other plants. Eur. J. Plant Pathol. 102:181-192.

7. Caten, C. E., and Jinks, J. L. 1968. Spontaneous variability of single isolates of Phytophthora infestans. I. Cultural variation. Can. J. Bot. 46:329-347.

8. Crute, I. R., and Pink, D. A. C. 1996. Genetics and utilization of pathogen resistance in plants. Plant Cell 8:1747-1755.

9. Daggett, S. S., Gotz, E., and Therrien, C. D. 1993. Phenotypic changes in populations of Phytophthora infestans from eastern Germany. Phytopathology 83:319-323.

10. Daggett, S. S., Knighton, J. E., and Therrien, C. D. 1995. Polyploidy among isolates of Phytophthora infestans from Eastern Germany. J. Phytopathol. 143:419-422.

11. de Wit, P. J. G. M. 1995. Fungal avirulence genes and plant resistance genes: Unraveling the molecular basis of gene-for-gene interactions. Adv. Bot. Res. 21:147-185.

12. Drenth, A., Tas, I. C. Q., and Govers, F. 1994. DNA fingerprinting uncovers a new sexually reproducing population of Phytophthora infestans in the Netherlands. Eur. J. Plant Pathol. 100:97-107.

13. Drenth, A., Whisson, S. C., Maclean, D. J., Irwin, J. A. G., Obst, N. R., and Ryley, M. J. 1996. The evolution of races of Phytophthora sojae in Australia. Phytopathology 86:163-169.

14. Fry, W. E., and Goodwin, S. B. 1995. Recent migrations of Phytophthora infestans. Pages 89-95 in: Phytophthora infestans 150. L. I. Dowley, E. Bannon, L. R. Cooke, T. Keane, and E. O'Sullivan, eds. Boole Press Ltd., Dublin, Ireland.

15. Fry, W. E., and Goodwin, S. B. 1997. Resurgence of the Irish potato famine fungus. Bioscience 47:363-371.

16. Fry, W. E., Goodwin, S. B., Dyer, A. T., Matsuzak, J. M., Drenth, A., Tooley, P. W., Sujkowski, L. S., Koh, Y. J., Cohen, B. A., Spielman, L. J., Deahl, K. L., Inglis, D. A., and Sandlan, K. P. 1993. Historical and recent migrations of Phytophthora infestans: Chronology, pathways, and implications. Plant Dis. 77:653-661.

17. Goodwin, S. B. 1997. The population genetics of Phytophthora. Phytopathology 87:462-473.

18. Goodwin, S. B., Cohen, B. A., and Fry, W. E. 1994. Panglobal distribution of a single clonal lineage of the Irish potato famine fungus. Proc. Natl. Acad. Sci. U.S.A. 91:11591-11595.
19. Goodwin, S. B., Drenth, A., and Fry, W. E. 1992. Cloning and genetic analyses of two highly polymorphic, moderately repetitive nuclear DNA's from Phytophthora infestans. Curr. Genet. 22:107-115.

20. Goodwin, S. B., Sujowski, L. S., and Fry, W. E. 1995. Rapid evolution of pathogenicity within clonal lineages of the potato late blight disease fungus. Phytopathology 85:669-676.

21. Grant, B. R., Ebert, D., and Gayler, K. R. 1996. Elicitins: Proteins in search of a role. Australas. Plant Pathol. 25:148-157.

22. Huet, J. C., Le Caer, J. P., Nespoulous, C., and Pernollet, J. C. 1995. The relationships between the toxicity and the primary and secondary structures of elicitinlike protein elicitors secreted by the phytopathogenic fungus Pythium vexans. Mol. Plant-Microbe Interact. 8:302-310.

23. Joosten, M. H. A. J., Cozijnsen, A. J., and de Wit, P. J. G. M. 1994. Host resistance to a fungal tomato pathogen lost by a single base-pair change in an avirulence gene. Nature 367:384-387.

24. Joosten, M. H. A. J., Vogelsang, R., Cozijnsen, T. J., Verberne, M. C., and de Wit, P. J. G. M. 1997. The biotrophic fungus Cladosporium fulvum circumvents $\mathrm{Cf}-4$ mediated resistance by producing unstable AVR4 elicitors. Plant Cell 9:367-379.

25. Judelson, H. J. 1996. Recent advances in the genetics of oomycete plantpathogens. Mol. Plant-Microbe Interact. 9:443-449.

26. Kamoun, S., Klucher, K. M., Coffey, M. D., and Tyler, B. M. 1993. A gene encoding a host-specific elicitor protein of Phytophthora parasitica. Mol. Plant-Microbe Interact. 6:573-581.

27. Kamoun, S., van West, P., de Jong, A. J., de Groot, K. E., Vleeshouwers, V. G. A. A., and Govers, F. 1997. A gene encoding a protein elicitor of Phytophthora infestans is down-regulated during infection of potato. Mol. Plant-Microbe Interact. 10:13-20.

28. Kamoun, S., van West, P., Vleeshouwers, V. G. A. A., de Groot, K. E. and Govers, F. 1998. Resistance of Nicotiana benthamiana to Phytophthora infestans is mediated by the recognition of the elicitor protein INF1. Plant Cell 10:1413-1426.

29. Kamoun, S., Young, M., Forster, H., Coffey, M. D., and Tyler, B. M. 1994. Potential role of elicitins in the interaction between Phytophthora species and tobacco. Appl. Environ. Microbiol. 60:1593-1598.

30. Kamoun, S., Young, M., Glascock, C., and Tyler, B. M. 1993. Extracellular protein elicitors from Phytophthora: Host-specificity and induction of resistance to fungal and bacterial phytopathogens. Mol. Plant-Microbe Interact. 6:15-25.

31. Knogge, W. 1996. Fungal infections of plants. Plant Cell 8:1711-1722.

32. Logemann, J., Schell, J., and Willmitzer, L. 1987. Improved method for isolation of RNA from plant tissue. Anal. Biochem. 163:16-20.

33. Merril, C. R., Goldman, D., Sedman, S. A., and Ebert, M. H. 1981. Ultrasensitive stain for proteins in polyacrylamide gels shows regional variation in cerebrospinal fluid proteins. Science 211:14371438.

34. Pernollet, J.-C., Sallantin, M., Salle-Tourne, M., and Huet, J.-C. 1993. Elicitin isoforms from seven Phytophthora species: Comparison of their physico-chemical properties and toxicity to tobacco and other plant species. Physiol. Mol. Plant Pathol. 42:53-67.

35. Pieterse, C. M. J., Risseeuw, E. P., and Davidse, L. C. 1991. An in planta induced gene of Phytophthora infestans codes for ubiquitin. Plant Mol. Biol. 17:799-811.

36. Ritch, D. L., and Daggett, S. S. 1995. Nuclear DNA content and chromosome number in German isolates of Phytophthora infestans. Mycologia $87: 579-581$.

37. Sambrook, J., Fritsch, E. F., and Maniatis, T. 1989. Molecular Cloning: A Laboratory Manual. Cold Spring Harbor Laboratory, Cold Spring Harbor, NY.

38. Schagger, H., and von Jagow, G. 1987. Tricine-sodium dodecyl sulfatepolyacrylamide gel electrophoresis for the separation of proteins in the range of 1 to $100 \mathrm{kDa}$. Anal. Biochem. 166:368-379.

39. Staskawicz, B. J., Ausubel, F. M., Baker, B. J., Ellis, J. G., and Jones, J. D. G. 1995. Molecular genetics of plant disease resistance. Science 268: 661-667.

40. Templeton, M. D., and Lamb, C. J. 1988. Elicitors and defense gene activation. Plant Cell Environ. 11:395-401.

41. Umaerus, V., and Umaerus, M. 1994. Inheritance of resistance to late blight. Pages 365-401 in: Potato Genetics. J. E. Bradshaw and G. R. Mackay, eds. CAB International, Wallingford, Oxon, United Kingdom.

42. Unkles, S. E., Moon, R. P., Hawkins, A. R., Duncan, J. M., and Kinghorn, J. R. 1991. Actin in the oomycetous fungus Phytophthora infestans is the product of several genes. Gene 100:105-112.

43. van den Ackerveken, G. F. J. M., van Kan, J. A. L., and de Wit, P. J. G. M. 1992. Molecular analysis of the avirulence gene $a v r 9$ of the fungal tomato pathogen Cladosporium fulvum fully supports the gene-for-gene hypothesis. Plant J. 2:359-366. 
44. van der Lee, T., De Witte, I., Drenth, A., Alfonso, C., and Govers, F. 1997. AFLP linkage map of the oomycete Phytophthora infestans. Fungal Genet. Biol. 21:278-291.

45. van Kan, J. A. L., van den Ackerveken, G. F. J. M., and de Wit, P. J. G. M. 1991. Cloning and characterization of cDNA of avirulence gene avr9 of the fungal pathogen Cladosporium fulvum, causal agent of tomato leaf mold. Mol. Plant-Microbe Interact. 4:52-59.

46. Vos, P., Hogers, R., Bleeker, M., Reijans, M., van der Lee, T., Hornes, M., Frijters, A., Pot, J., Peleman, J., Kuiper, M., and Zabeau, M. 1995. AFLP: A new technique for DNA fingerprinting. Nucleic Acids Res.
23:4407-4414.

47. Wastie, R. L. 1991. Breeding for resistance. Pages 193-224 in: Phytophthora infestans, the cause of late blight of potato. Advances in Plant Pathology, vol. 7. D. S. Ingram and P. H. Williams, eds. Academic Press, New York.

48. Yu, L. M. 1995. Elicitins from Phytophthora and basic resistance in tobacco. Proc. Natl. Acad. Sci. U.S.A. 92:4088-4094.

49. Zwankhuizen, M. J., Govers, F., and Zadoks, J. C. 1998. Development of potato late blight epidemics: Disease foci, disease gradients, and infection sources. Phytopathology 88:754-763. 